\title{
Prevalence of low back pain and associated factors among office workers in Kano city, Nigeria
}

\author{
Muhammad Nuhu Salihu', Mamman Muhammad Lawal', Abuhuraira Ado Musa, ${ }^{12,}$, \\ Yusuf Muhammad Abdullahi, ${ }^{4,5}$, Maryam Dahiru Umar ${ }^{6}$, Oruche Chinyere Amaka ${ }^{7}$, \\ Jacob Jonah Addi ${ }^{8}$, Faisal Muhammad ${ }^{9 *}$
}

\begin{abstract}
${ }^{1}$ Department of Clinical Services, National Orthopedic Hospital Dala, Kano, Nigeria
${ }^{2}$ Department of Public Health, National Orthopedic Hospital Dala, Kano, Nigeria

${ }^{3}$ Department of Medical Microbiology and Parasitology, Faculty of Clinical Sciences, Bayero University Kano (BUK), Kano, Nigeria

${ }^{4}$ Africa Centre of Excellence, Centre for Public Health and Toxicological Research (ACE-PUTOR), University of Port Harcourt (UNIPORT), Port Harcourt, Nigeria

${ }_{5}^{5}$ Department of Environmental Health, Primary Health-Care Management Board, Kano, Nigeria

${ }^{6}$ Department of Obstetrics and Gynecology, Faculty of Clinical Sciences, BUK, Kano, Nigeria

${ }^{7}$ Department of Development Studies, Faculty of Social Sciences, University of Dhaka (DU), Dhaka Bangladesh

${ }^{8}$ Department of Economics, Faculty of Social Sciences, BUK, Kano, Nigeria

${ }^{9}$ Department of Public Health, Faculty of Allied Health Science, Daffodil International University (DIU), Dhaka

Bangladesh
\end{abstract}

Received: 11 January 2021

Revised: 14 July 2021

Accepted: 15 July 2021

\section{*Correspondence:}

Faisal Muhammad,

E-mail: fokkanya@yahoo.com

Copyright: ( $)$ the author(s), publisher and licensee Medip Academy. This is an open-access article distributed under the terms of the Creative Commons Attribution Non-Commercial License, which permits unrestricted non-commercial use, distribution, and reproduction in any medium, provided the original work is properly cited.

\begin{abstract}
Background: Many studies across the globe have reported the prevalence of low back pain (LBP) among office workers. This study aimed to find out the prevalence of LBP and associated factors among office workers in Kano city, Nigeria.

Methods: A cross-sectional type of study was conducted among the office workers in Kano metropolitan from September to December 2019. A total of 300 office workers were selected using a convenience sampling technique. The data was collected from the respondents by face-to-face interview technique using a semi-structured questionnaire and all the data collected were analyzed using statistical software (SPSS version 22.0).

Results: In this study, the mean age of the respondents was $38.6 \pm 9.6$ years and $72.7 \%$ of them were male. More than half $(54.7 \%)$ of the respondents had a bachelor's degree and above. About $71.3 \%$ of the respondents had a familial history of LBP. About $68.0 \%$ of the respondents had suffered musculoskeletal disorder in the past and the majority $(54.4 \%)$ mentioned they suffered hip pain. Only $33.7 \%$ of the respondents were maintaining the proper posture and $37.7 \%$ of the respondents were using an ergonomic chair.

Conclusions: The findings of this study found a $65.3 \%$ prevalence of low back pain among the office workers in Kano metropolitan. Office workers should be encouraged to maintain proper postures at work and there is a need for more educational programs regarding the prevention measures of low back pain.
\end{abstract}

Keywords: Low back pain, Office workers, Occupational health, Kano 


\section{INTRODUCTION}

Low back pain (LBP) is among the most common causes of musculoskeletal disorders related to work status and condition. ${ }^{1}$ It was estimated that about $80.0 \%$ of the general population will experience a back problem at some time in their lives. ${ }^{2}$ LBP can induce a lack of mental unrest, enthusiasm as well as physical discomfort. ${ }^{3}$ It was reported that among the working population, the LBP became a significant cause of taking sick leave as well as early retirement. ${ }^{4}$ LBP has been recognized as one of the major causes for decreased efficiency and well-being in the working populace..$^{5-7}$ Office workers are characterized to spend a substantial amount of time sitting at a desk. Many studies have shown different levels of the prevalence of LBP among office workers. ${ }^{8-10}$ The prevalence of LBP in high-income countries was found to be lower than that of low-income countries. ${ }^{11}$

LBP was reported to account for an average number of disability-adjusted life years (DALYs) higher than road injuries, chronic obstructive pulmonary disease (COPD,) HIV, tuberculosis, lung cancer and preterm birth complications. ${ }^{12}$ In 1990, LBP was estimated to contribute around 58.2 million DALYs to the global burden of disease, ranking it as the 11th leading global contributor to years lost from premature mortality or years lived in ill health. Later in 2010, LBP was ranked as the sixth leading contributor to overall disease burden, with an estimation of about 83 million DALYs. ${ }^{13}$ Numerous studies have been conducted across the globe to evaluate as well as explore the social and economic impact of LBP. A study conducted in the United Kingdom reported LBP as the most common cause of disability in young adults, with above 100 million workdays lost per year. ${ }^{12}$ It was estimated that close to 150 million workdays are lost every year because of LBP in the United States. ${ }^{14,15}$ This study aimed to find out the prevalence of LBP and associated factors among office workers in Kano city, Nigeria.

\section{METHODS}

\section{Study setting and period}

This study was carried out in Kano metropolitan, a capital city of Kano state in the North-West zone of Nigeria. It is the commercial nerve center of Northern Nigeria as well as the second largest city all over the country. The study was conducted for a period of three months (September to December 2019).

\section{Study design, population and selection criteria}

This was a descriptive cross-sectional study conducted in Kano metropolitan in the North-Western part of Nigeria. The study populations were all the office workers (such as healthcare providers, bankers, teachers, legal practitioners, business administrators, offices secretaries, social workers) in Kano metropolitan, who were available during the period of this study and willing to participate.

\section{Sample and sampling technique}

A total of three hundred (300) office workers from different areas across the eight local governments (Dala, Fagge, Gwale, Kano-Municipal, Kumbotso, Nassarawa, Tarauni and Ungogo) in the Kano metropolitan were selected using a convenience sampling technique.

\section{Data collection and analysis}

The data was collected from the respondents by face-toface interview technique using a semi-structured questionnaire. Written and verbal informed consent was taken from the respondents before the data collection. All the data collected were coded numerically and entered into statistical software (SPSS version 22.0) for analysis. A Chi-square test was performed to find the association between variables and a $p$ value of $\leq 0.05$ was considered statistically significant.

\section{RESULTS}

\section{Socio-demographic characteristics of the respondents}

Table 1 shows that seven-tenths $(70.0 \%)$ of the respondents were 36 years and above and the mean age of the respondents was $38.6 \pm 9.6$ years. About $72.7 \%$ of the respondents were male and more than half $(54.7 \%)$ had bachelor's degrees and above. More than seven-tenths $(74.0 \%)$ of the respondents were married and the rest were unmarried $(26.0 \%)$. Nevertheless little below nine-tenths $(89.3 \%)$ of the respondents were from urban areas and the rest $(10.7 \%)$ were residing in rural areas.

Figure 1 shows the prevalence of low back pain among the respondents of this study, the prevalence of LBP was $65.3 \%$ among the office workers in Kano metropolitan.

\section{Distribution based on LBP risk factors}

Table 2 shows that about $71.3 \%$ of the respondents had a familial history of LBP and more than half (57.0\%) of the history was paternal. About $68.0 \%$ of the respondents had suffered musculoskeletal disorder in the past and the majority (54.4\%) mentioned they suffered hip pain, followed by knee pain $(39.7 \%)$. In this study less than onetenth $(7.0 \%)$ of the respondents were smokers and only $37.0 \%$ were exercising regularly. Little above two-fifths $(41.7 \%)$ of the respondents used to take meals regularly and close to six-tenths $(59.7 \%)$ of the respondents mentioned they were getting less than 6 hours of sleep a day. 
Table 1: Socio-demographic characteristics of the respondents $(\mathrm{N}=300)$.

\begin{tabular}{|lll|}
\hline Variables & Frequency & Percent \\
\hline Ages (in years) & & 30.0 \\
\hline$\leq 35$ & 90 & 70.0 \\
\hline$\geq 36$ & 210 & \\
\hline Mean \pm SD & $38.6 \pm 9.6$ & 72.7 \\
\hline Sex & & 27.3 \\
\hline Male & 218 & \\
\hline Female & 82 & 45.3 \\
\hline Educational level & & 54.7 \\
\hline Diploma/NCE and below & 136 & \\
\hline Bachelor's degree and above & 164 & 74.0 \\
\hline Marital status & & 26.0 \\
\hline Married & 222 & \\
\hline Unmarried & 78 & 10.7 \\
\hline Residence & & 89.3 \\
\hline Rural & 32 & \\
\hline Urban & 268 & \\
\hline
\end{tabular}

Table 2: Distribution based on LBP risk factors $(\mathrm{N}=300)$.

\begin{tabular}{|c|c|c|}
\hline Variables & Frequency & Percentage \\
\hline \multicolumn{3}{|c|}{ Family history of LBP } \\
\hline Yes & 214 & 71.3 \\
\hline No & 86 & 28.7 \\
\hline \multicolumn{3}{|c|}{ If yes who? (N=214) (multiple response) } \\
\hline Father & 122 & 57.0 \\
\hline Mother & 99 & 46.3 \\
\hline Others & 88 & 41.1 \\
\hline \multicolumn{3}{|c|}{ Had musculoskeletal disorder } \\
\hline Yes & 204 & 68.0 \\
\hline No & 96 & 32.0 \\
\hline \multicolumn{3}{|c|}{ If yes, which? ( $\mathrm{N}=204)$ (multiple response) } \\
\hline Knee pain & 81 & 39.7 \\
\hline Hip pain & 111 & 54.4 \\
\hline Wrist pain & 74 & 36.3 \\
\hline Others & 44 & 21.6 \\
\hline \multicolumn{3}{|c|}{ Smoking status } \\
\hline Yes & 21 & 7.0 \\
\hline No & 279 & 93.0 \\
\hline \multicolumn{3}{|c|}{ Physical exercises } \\
\hline Yes & 111 & 37.0 \\
\hline No & 189 & 63.0 \\
\hline \multicolumn{3}{|c|}{ Habit of taking meal } \\
\hline Regularly & 125 & 41.7 \\
\hline Irregularly & 175 & 58.3 \\
\hline \multicolumn{3}{|c|}{ Sleeping hours } \\
\hline$<6$ & 179 & 59.7 \\
\hline$\geq 6$ & 121 & 40.3 \\
\hline
\end{tabular}

Table 3: Distribution based on occupational and psychological factors $(\mathrm{N}=300)$.

Variables

Maintaining proper posture

Yes

\section{Frequency}

101

\section{Percentage}

33.7 


\begin{tabular}{|lll|}
\hline Variables & Frequency & Percentage \\
\hline No & 199 & 66.3 \\
\hline Using ergonomic chair & & \\
\hline Yes & 113 & 37.7 \\
\hline No & 187 & 62.3 \\
\hline Weekly working hours & & \\
\hline$<25$ & 131 & 43.7 \\
\hline$\geq 25$ & 169 & 56.3 \\
\hline Job satisfaction & & \\
\hline Yes & 97 & 32.3 \\
\hline No & 203 & 67.7 \\
\hline Work related stress & & \\
\hline Yes & 117 & 39.0 \\
\hline No & 183 & 61.0 \\
\hline Family related stress & & \\
\hline Yes & 77 & 25.7 \\
\hline No & 223 & 74.3 \\
\hline Financial related stress & & \\
\hline Yes & 213 & 71.0 \\
\hline No & 87 & 29.0 \\
\hline
\end{tabular}

Table 4: Relationship between prevalence of LBP and other related factors $(N=300)$.

\begin{tabular}{|c|c|c|c|c|c|}
\hline \multirow{2}{*}{ Variables } & \multicolumn{2}{|c|}{ Prevalence } & \multirow{2}{*}{ Chi-square } & \multirow{2}{*}{ Df } & \multirow{2}{*}{$\begin{array}{l}\mathbf{P} \\
\text { value }\end{array}$} \\
\hline & Yes & No & & & \\
\hline \multicolumn{6}{|c|}{ Age (in years) } \\
\hline$\leq 30$ & 32 & 58 & \multirow{2}{*}{19.848} & \multirow{2}{*}{1} & \multirow{2}{*}{$<0.001$} \\
\hline$\geq 36$ & 164 & 46 & & & \\
\hline \multicolumn{6}{|l|}{ Sex } \\
\hline Male & 117 & 101 & \multirow{2}{*}{2.946} & \multirow{2}{*}{1} & \multirow{2}{*}{0.086} \\
\hline Female & 79 & 3 & & & \\
\hline \multicolumn{6}{|c|}{ Family history of LBP } \\
\hline Yes & 126 & 88 & \multirow{2}{*}{13.733} & \multirow{2}{*}{1} & \multirow{2}{*}{$<0.001$} \\
\hline No & 70 & 16 & & & \\
\hline \multicolumn{6}{|c|}{ Habit of taking meal } \\
\hline Regularly & 62 & 63 & \multirow{2}{*}{20.504} & \multirow{2}{*}{1} & \multirow{2}{*}{$<0.001$} \\
\hline Irregularly & 134 & 41 & & & \\
\hline \multicolumn{6}{|c|}{ Sleeping hours } \\
\hline$<6$ & 133 & 46 & \multirow{2}{*}{5.820} & \multirow{2}{*}{1} & \multirow{2}{*}{0.016} \\
\hline$\geq 6$ & 63 & 58 & & & \\
\hline \multicolumn{6}{|c|}{ Physical exercises } \\
\hline Yes & 45 & 66 & \multirow{2}{*}{47.817} & \multirow{2}{*}{1} & \multirow{2}{*}{$<0.001$} \\
\hline No & 151 & 38 & & & \\
\hline \multicolumn{6}{|c|}{ Smoking status } \\
\hline Yes & 20 & 1 & 8016 & 1 & 0,003 \\
\hline No & 176 & 103 & 8.910 & 1 & 0.003 \\
\hline Maintainiı & & & & & \\
\hline Yes & 11 & 90 & 177 & 1 & $<0001$ \\
\hline No & 185 & 14 & $1.1 / 2$ & 1 & $<0.001$ \\
\hline Using ergo & & & & & \\
\hline Yes & 15 & 98 & 1840 & 1 & $<0001$ \\
\hline No & 181 & 6 & 1.040 & 1 & 0.001 \\
\hline Weekly wc & & & & & \\
\hline$<25$ & 46 & 85 & 26431 & 1 & $<0001$ \\
\hline$\geq 25$ & 150 & 19 & 20.451 & 1 & -0.001 \\
\hline
\end{tabular}




\begin{tabular}{|c|c|c|c|c|c|}
\hline \multirow{2}{*}{ Variables } & \multicolumn{2}{|c|}{ Prevalence } & \multirow{2}{*}{ Chi-square } & \multirow{2}{*}{ Df } & \multirow{2}{*}{$\begin{array}{l}P \\
\text { value }\end{array}$} \\
\hline & Yes & No & & & \\
\hline \multicolumn{6}{|c|}{ Work related stress } \\
\hline Yes & 101 & 16 & \multirow{2}{*}{9.284} & \multirow{2}{*}{1} & \multirow{2}{*}{0.002} \\
\hline No & 95 & 88 & & & \\
\hline \multicolumn{6}{|c|}{ Family related stress } \\
\hline Yes & 71 & 6 & \multirow{2}{*}{33.032} & \multirow{2}{*}{1} & \multirow{2}{*}{$<0.001$} \\
\hline No & 125 & 98 & & & \\
\hline \multicolumn{6}{|c|}{ Financial related stress } \\
\hline Yes & 120 & 93 & \multirow{2}{*}{26.240} & \multirow{2}{*}{1} & \multirow{2}{*}{$<0.001$} \\
\hline No & 76 & 11 & & & \\
\hline
\end{tabular}

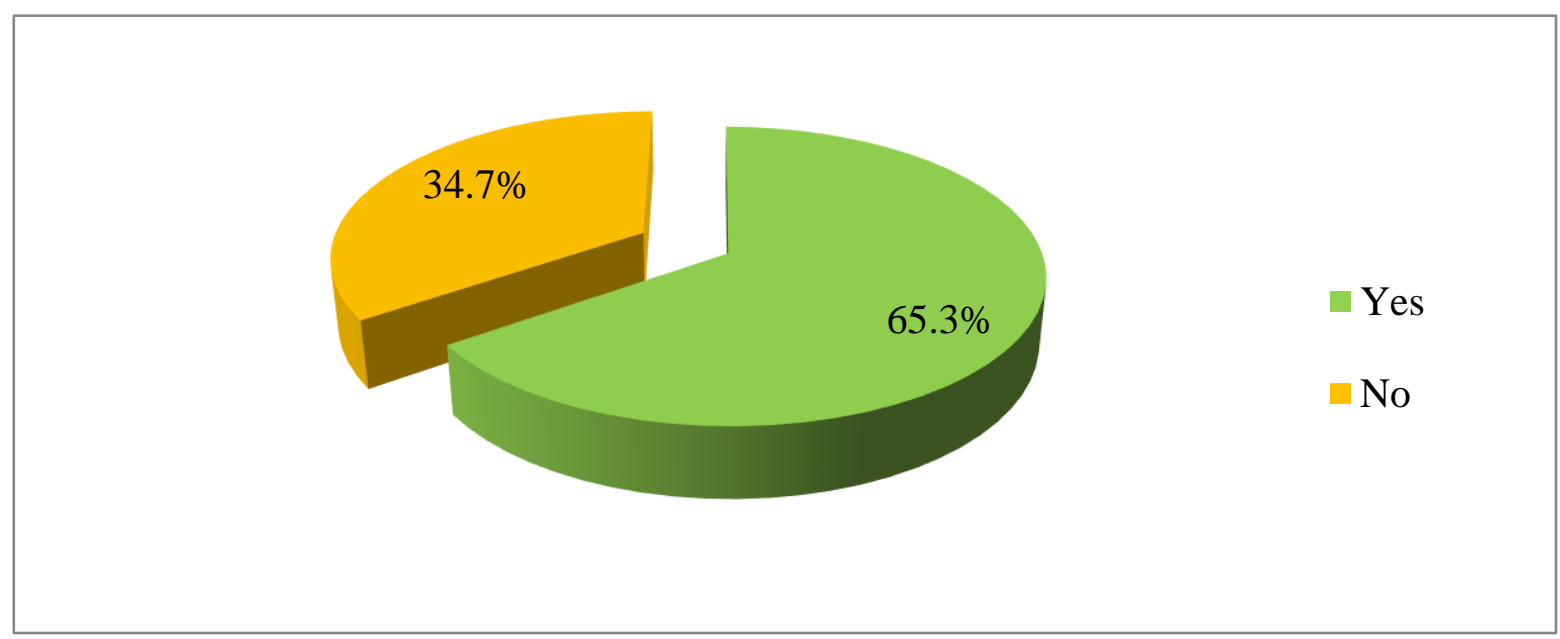

Figure 1: Prevalence of LBP $(\mathrm{N}=300)$.

\section{Distribution based on occupational and psychological factors}

Table 3 shows that $33.7 \%$ of the respondents were maintaining the proper posture and $37.7 \%$ of the respondents were using an ergonomic chair. About 56.3\% of the respondents used to have about 25 or more working hours every week and only $32.3 \%$ of them were satisfied with their jobs. Close to two-fifths $(39.0 \%)$ of the respondents had faced work-related stress, $25.7 \%$ familyrelated stress, and $71.0 \%$ financial-related stress.

\section{Relationship between prevalence of $\mathrm{LBP}$ and other related factors $(N=300)$}

Table 4 shows that the prevalence of LBP was significantly associated with the age of the respondents, family history of LBP, the habit of taking a meal, sleeping hours, physical exercises, smoking status, maintaining proper posture, using an ergonomic chair, weekly working hours, workrelated stress. Family-related stress and financial-related stress. However, the gender of the respondents was not significantly associated with the prevalence of LBP.

\section{DISCUSSION}

This study aimed to find out the prevalence of LBP and associated factors among office workers in Kano city, Nigeria. In this study, the mean age of the respondents was 38.6 \pm 9.6 years. This was consistent with that of a similar study conducted among healthcare workers in Sokoto, Nigeria. ${ }^{16}$ About $72.7 \%$ of the respondents were male, this was inconsistent with the finding of a similar study conducted in the southern part of Nigeria. ${ }^{17}$

The prevalence of LBP among the office workers in Kano metropolitan was found to be $65.3 \%$. A similar study conducted among professional drivers in Kano reported a $73.5 \%$ prevalence of low back pain. ${ }^{18}$ Another study conducted in Dhaka, Bangladesh among bank employees reported the prevalence of $36.6 \%$ which was inconsistent with that of our study. ${ }^{19}$ A study conducted in Nigeria found a $59.7 \%$ prevalence of LBP among industrial workers. ${ }^{20}$ More than half of the respondents used to have about 25 or more working hours every week. A study conducted in Denmark reveals that workers who spent a long time at the office were found to have a higher rate of low back pain. ${ }^{21}$ 
The prevalence of LBP was significantly associated with the age of the respondents, a study reported increasing age as a significant risk factor for low back pain. ${ }^{22}$ Another study also revealed that older adults were reported to have LBP than young adults. ${ }^{19}$ Maintaining proper posture, weekly working hours and work-related stress were significantly associated with low back pain. A study carried out in Nigeria among healthcare providers reported that the respondents believed that poor posture, heavy physical work and prolonged sitting were responsible for their LBP. ${ }^{16}$ Smoking status was found significantly associated with LBP in this study. A similar study conducted in Nigeria found that smoking status was not significantly associated with LBP. ${ }^{20}$

In this study, regular physical exercise was significantly associated with LBP. Some studies on LBP reported that routine physical activity could reduce LBP. ${ }^{23,24}$ However gender of the respondents was not significantly associated with the prevalence of LBP. A similar study from Bangladesh reported that gender was not significantly associated with LBP. ${ }^{19}$ Nevertheless a systematic review revealed that the prevalence of LBP was increased for women relative to men. ${ }^{25}$

\section{CONCLUSION}

The findings of this study found a $65.3 \%$ prevalence of low back pain among the office workers in Kano metropolitan. However the prevalence of low back pain was significantly associated with the age of the respondents, family history of low back pain, the habit of taking a meal, sleeping hours, physical exercises, smoking status, maintaining proper posture, using an ergonomic chair, weekly working hours, work-related stress. Family-related stress and financial-related stress. Nevertheless, the gender of the respondents was not significantly associated with the prevalence of low back pain.

\section{Recommendations}

Office workers should be encouraged to maintain proper postures at work and there is a need for more educational programs regarding the prevention measures of low back pain. We also recommend a similar study to assess the level of knowledge and practice regarding prevention measures of LBP among the office workers in Kano metropolitan.

\section{Funding: No funding sources}

Conflict of interest: None declared

Ethical approval: The study was approved by the institutional ethics committee

\section{REFERENCES}

1. Cunningham C, Flynn T, Blake C. Low back pain and occupation among Irish health workers. Occup Med. 2006;56(7):23-8.
2. Mafuyai MY, Babangida BG, Mador ES, Bakwa DD, Jabil YY. The increasing cases of lower back pain in developed Nations: a reciprocal effect of development. AJIS. 2014;3(5):23-8.

3. Hanna F, Daas RN, El-Shareif TJ, Al-Marridi HH, Al-Rojoub ZM, Adegboye OA. The relationship between sedentary behavior, back pain, and psychosocial correlates among university employees. Front Public Heal. 2019;7:80.

4. Lotters F, Burdorf A. Prognostic factors for duration of sickness absence due to musculoskeletal disorders. Clin J Pain. 2006;22(2):212-21.

5. Miyamoto M, Konno S, Gembun Y, Xinyu Liu, Kazufumi Minami, Hiromoto Ito H. Epidemiological study of low back pain and occupational risk factors among taxi drivers. Ind Health. 2008;46(2):112-7.

6. Dagenais S, Caro J, Haldeman S. A systematic review of low back pain cost of illness studies in the United States and internationally. Spine. 2008;8(1):8-20.

7. Tulder MWV, Koes BW, Bouter LM. A cost-ofillness study of back pain in The Netherlands. Pain. 1995;62(2):233-40.

8. Andersen JH, Gaardboe O, Anderson SP, Oakman J, Article O, Arvidsson I, et al. National institute for working life ergonomic expert committee document no 1visual display unit work and ... committee document no 1 visual display unit work and upper extremity musculoskeletal disorders a review of epidemiological findings. Appl Ergon. 2015;7(1):3741.

9. Ayanniyi O, Ukpai B, Adeniyi A. Differences in prevalence of self-reported musculoskeletal symptoms among computer and non-computer users in a Nigerian population: a cross-sectional study. BMC Musculoskelet Disord. 2010;11(1):177.

10. Hameed S. Prevalence of work-related low back pain among the information technology professionals in India-a cross-sectional study. Int J Sci Technol Res. 2013;2(7).

11. Campos-Fumero A, Delclos GL, Douphrate DI, Felknor SA, Vargas-Prada S, Serra C, et al. Low back pain among office workers in three Spanish-speaking countries: findings from the CUPID study. Inj Prev. 2017;23(3):158-64.

12. Vos T, Flaxman A, Naghavi M, Lozano R, Michaud C, Ezzati M, et al. Years lived with disability (YLDs) for 1160 sequelae of 289 diseases and injuries 19902010: a systematic analysis for the Global Burden of Disease Study 2010. Lancet. 2012;380(9859):216396.

13. Murray C, Vos T, Lozano R, Naghavi M, Flaxman A, Michaud C, et al. Disability-adjusted life years (DALYs) for 291 diseases and injuries in 21 regions, 1990-2010: a systematic analysis for the global burden of disease study 2010. Lancet. 2012;30:2197223.

14. CDC. Fact sheet: Preventing back injuries in health care settings. Atlanta, USA: Centers for Disease Control and Prevention 2008. Available at: http//: 
blogs.cdc.gov/niosh-scienceblog/2008/09/22/lifting. Accessed on 27 December 2020.

15. Ansari MA, Subedi K, Panta OB, Suwal S. MRI pattern of lumbosacral degeneration in Tribhuvan University Teaching Hospital, Nepal. JIOM. 2015;38(2):51-5.

16. Awosan KJ, Yikawe SS. Prevalence, perception and correlates of low back pain among healthcare workers in tertiary health institutions in Sokoto, Nigeria, Oche M. Oche Muhammad Oboirien Ghana Med J. 2017;51(4):164-74.

17. Johnson OE, Edward E. Prevalence and risk factors of low back pain among workers in a health facility in South-South Nigeria. BJMMR. 2016;11(8):1-8.

18. Rufa'I AA, Sa'idu IA, Ahmad RY, Elmi OS, Aliyu SU, Jajere AM, et al. Prevalence and risk factors for low back pain among professional drivers in Kano, Nigeria. Archiv Environment Occupation Health. 2015:70(5):251-5.

19. Ali M, Ahsan GU, Hossain A. Prevalence and associated occupational factors of low back pain among the bank employees in Dhaka City. J Occup Health. 2020;62(1):12131.

20. Sanya AO, Ogwumike OO. Low back pain prevalence amongst industrial workers in the private sector in Oyo State, Nigeria. Afr J Med Medic Sci. 2005;34(3):245-9.
21. Gupta N, Christiansen CS, Hallman DM, Korshøj M, Carneiro IG, Holtermann A. Is objectively measured sitting time associated with low back pain? A crosssectional investigation in the NOMAD study. PLoS One. 2015;10(3):0121159.

22. Wong AY, Karppinen J, Samartzis D. Low back pain in older adults: risk factors, management options and future directions. Scoliosis Spinal Disord. 2017;12(1):14.

23. Hossain MD, Aftab A, AlImam MH, Mahmud I, Chowdhury IA, Kabir RI, et al. Prevalence of work related musculoskeletal disorders (WMSDs) and ergonomic risk assessment among readymade garment workers of Bangladesh: A cross sectional study. PLoS One. 2018;13(7):0200122.

24. Gordon R, Bloxham S. A systematic review of the effects of exercise and physical activity on nonspecific chronic low back pain. Healthcare. 2016;4(2):22.

25. Wáng YXJ, Wáng JQ, Káplár Z. Increased low back pain prevalence in females than in males after menopause age: evidences based on synthetic literature review. Quant Imaging Med Surg. 2016;6(2):199-206.

Cite this article as: Salihu MN, Lawal MM, Musa AA, Abdullahi YM, Umar MD, Amaka OC, et al. Prevalence of low back pain and associated factors among office workers in Kano city, Nigeria. Int J Res Orthop 2021;7:907-13. 